\section{Seasonal effect on nutrient intake in adults living in Southern Brazil}

\author{
Efeito da sazonalidade sobre a ingestão de \\ nutrientes em adultos residentes no Sul do Brasil
}

\author{
1 Programa de Pós-graduação \\ em Saúde Coletiva \\ Universidade do Vale do Rio \\ dos Sinos, São Leopoldo, \\ Brasil. \\ 2 Faculdade de Nutrição, \\ Universidade Federal \\ Fluminense, Niterói, Brasil. \\ Correspondence \\ M. T. A. Olinto \\ Programa de Pós-graduação \\ em Saúde Coletiva, \\ Universidade do Vale do Rio \\ dos Sinos. \\ Av. Unisinos 950, C. P. 275 \\ São Leopoldo, RS 93022-000, \\ Brasil. \\ mtolinto@unisinos.br
}

Abstract

The objective of this study was to investigate the effect of seasonality on nutrient intake in healthy adults from the southernmost metropolitan area of Brazil. The dietary intake (24-hour dietary recall on six different days) in a sample of 162 adults (114 women), aged 20 to 69, was obtained during the year 2007. The nutrient intake was averaged for each season and adjusted for energy intake using the residual method. The effect of season on energy, macro and micro-nutrient intake was investigated based on the Generalized Estimate Equations (GEE) model. There were statistically significant differences between seasons for carbohydrate and total fat intake after controlling for gender, age, education, and interactions. In summer carbohydrate intake was higher than other seasons while the total fat intake was lower. These findings highlight the importance of considering seasonal variations not only for evaluating dietary intake but also nutrition and public health policy recommendations, particularly in adult populations living in temperate regions.

Eating; Nutrition Policy; Seasons
Sinara Laurini Rossato 1

Maria Teresa Anselmo Olinto 1

Ruth Liane Henn 1

Luiz Antonio dos Anjos 2

Ana Weigert Bressan 1

Vivian Wahrlich 2

\section{Introduction}

The seasonal effect on health conditions has been documented in the literature $1,2,3$. Children from very poor areas of the world are at higher risk of diarrhea infections, weight loss, and malnutrition in the summer months 1,2. Colder temperatures seem to influence the appearance of bulimia 3 and a form of recurrent depression or bipolar disorder known as seasonal affective disorder (SAD) 4 .

Climate influences some physiological functions which may, in part, be related to changes in food intake. Metabolism is thought to be higher during the winter months 5 and this seasonal adaptation can be influenced by age and gender 6 . Other studies associate seasonality with changes in serum levels of nutrients such as vitamin D 7 and cholesterol ${ }^{8}$. According to Minghelli et al. 9, lower availability of food during the summer has led to weight reduction, loss of muscle mass, and lower diet-induced thermogenesis in adult Gambians. The seasonal differences in nutrient intake, mainly vitamins and minerals, depend on the availability of foods 10. A study carried out on farm workers and non-farm families from Washington State documented that the consumption of vegetable and fruits varied across seasons according to the harvest period 11 .

As in many countries, the production of fruits, vegetables, and meats is strongly influenced by the climate in Brazil 12. Although most of Brazil is 
situated in the tropics (below the Equator) with very little climatic change, the southernmost region of the country is in the temperate zone with marked seasonal (subtropical) climates. Data from the Brazilian Household Budget Survey 2002-2003 (POF 2003) 13 showed differences of household food availability among the five major Brazilian regions. The relative participation of meat, wheat meal and dairy products in diets in the South Region was high, but household bean consumption was lower than others regions. Although fruits, vegetables and legumes in the diet were below the recommended daily intake, the Southern diet showed higher relative participation of these items compared with the North, Northeast and Center-West regions 14.

Despite the existence of four clearly defined seasons during the year in the South of Brazil and the peculiarities of the eating habits of this population, to the best of the authors' knowledge no studies regarding this subject have been carried out. The purpose of the present study was to investigate the effect of seasonality on food intake in healthy adults from the southernmost metropolitan area of Brazil.

\section{Methods}

The data of the present analysis comes from a large study aimed at constructing and validating a food frequency questionnaire (FFQ) 15 developed by the Universidade do Vale do Rio dos Sinos (UNISINOS). It is a longitudinal study carried out in the metropolitan region of Porto Alegre in the state of Rio Grande do Sul, Southern Brazil. A total of 162 volunteers were recruited through advertisements in local newspapers and the distribution of pamphlets. This sample size was estimated for the FFQ validity study 16 . To be eligible to participate in the study the subjects had to be between 20 and 69 years of age, free of sicknesses (diabetes, hypertension, renal insufficiency, gastro-intestinal diseases), could not be on any kind of diet, and should not be pregnant or nursing. The age was categorized as 20 to 39 years old and 40 to 69 years old, guided by previous studies carried out in São Leopoldo, Rio Grande do Sul State, that identified changes in dietary patterns of women aged 40 and above 17 .

Data collection was carried out at two research units located in São Leopoldo and Porto Alegre, $30 \mathrm{~km}$ from one another, during the year 2007.

The study consisted of six interviews per individual throughout the year, and in each one, a 24 -hour dietary recall $(24 \mathrm{hR})$ was applied. On the first visit, demographic characteristics such as gender, age and education (described in com- plete years of formal schooling) were obtained using standardized questionnaires. All interviews were conducted by intensively trained interviewers. A photographic food album especially produced for this study was used to facilitate the identification of the foods ingested and their portion size. The album contains 224 photos showing foods with different sizes and presentations. It was based on the foods more frequently eaten by adults in a household survey ${ }^{18}$. Field work quality was controlled by conducting continuous training sessions, supervision of the field work, and periodic meetings.

The months considered for each season are: Summer (December, January and February), Autumn (March, April, May), Winter (June, July, August) and Spring (September, October, November). However, no data were collected in May, June and December.

\section{Calculation of nutrient intake}

The mean daily consumption of macro- and micronutrients was obtained by computing the food intake (in grams), versus the nutrient content for 100 grams of food as described in the Brazilian Food Composition Table (TACO, version 2. Núcleo de Estudos e Pesquisas em Alimentação, Universidade Estadual de Campinas, Campinas, Brazil). Alternatively, the USDA National Nutrient Database for Standard Reference - Release 20 tables (United States Department of Agriculture. Food search for Windows, version 1.0, database SR20. http://www.ars.usda.gov/ Services/docs.htm?docid=5720, accessed on 12/ Nov/2007) was used for the foods not found in the Brazilian table. The third alternative was the Table for the Assessment of Food Consumption and Portion Sizes 19, and food labels was consulted as the last option. The analysis of nutritional composition based on the TACO table includes 276 out of 1,358 analyzed foods (20\%), the USDA table accounts for 202 (15\%), and the Table for the Assessment of Food Consumption and Portion Sizes only 18 (1\%). The search for data on nutritional composition in food labels was performed for 63 (5\%) foods analyzed. Many of the foods listed were recipes, homemade mixtures or preparations. To calculate the nutritional composition of these foods, it was necessary to break down the recipes and calculate the ingredients one by one; this was necessary for 779 (59\%) foods. The nutritional composition from these recipes was computed based on previously mentioned tables, with similar proportions as described above.

The components included in analysis were energy (kcal), proteins (g), lipids (g), carbohy- 
drates (g), fiber (g) retinol (mcg of retinol), cholesterol (mg), vitamin C (mg), calcium (mg), and iron (mg).

\section{Statistical analysis}

Absolute and relative numbers were used to assess the distribution of repeated measures of $24 \mathrm{hR}$ according to the seasons and demographic characteristics of the sample.

The means of nutrient intakes were adjusted for energy by computing the regression model residuals with the energy intake as the independent variable and the nutrient intake as the dependent variable 16 . As the linear regression analysis assumes that the distribution of the dependent variable must be normal, the normality was tested using the Kolmogorov-Smirnov test 20 . All nutrients showed asymmetric distribution ( $\mathrm{p}<$ 0.001 ), thus they were transformed into natural logarithms before the analysis.

The Generalized Estimate Equation model (GEE) was used with an unstructured correlation matrix to assess the effect of seasons on nutrient intake. The nutrient intake was included in the model as dependent variable and the seasons as predictor. The log link function was employed since the relationship between the dependent variable and predictor was not linear. The analysis was performed unadjusted and then controlled for age, gender and schooling. One at a time, the interactions were added (gender/seasons, age/seasons and schooling/ seasons) and assessed the goodness of fit. The comparisons were based on pairwise contrast using sequential Bonferroni adjustment for multiple comparisons. GEE display quasi-likelihood under the independence model criterion (QIC) for choosing the best correlation structure and the best subset of predictors. The level of significance considered was $5 \%$. The data were analyzed using SPSS for Windows, version 16.0 (SPSS Inc., Chicago, USA).

The study was approved by the Institutional Review Board of the UNISINOS. Written informed consent was obtained from all participants prior to participation.

\section{Results}

A total of 792 24-hour recalls were applied for 162 participants. The characteristics of the sample and the number of $24 \mathrm{hR}$ conducted in each season are shown in Table 1. The participants were predominantly women $(70.4 \%)$ and the mean age was 38.45 years (95\%CI: 36.3-40.6). This sample had high education, averaging 11 years of study.
Table 1 shows that an inferior number of $24 \mathrm{hR}$ were answered during spring (17.8\%).

Table 2 shows the differences in energy and nutrient intake between seasons. The results were based on estimated mean nutrient intake adjusted for energy 16 . Only carbohydrate and total fat intake showed differences after adjustment. The carbohydrate intake was higher in summer compared to autumn, winter and spring, respectively, 15.8, 18.1 and 18.3g. The opposite was observed for total fat: the intake was always lower in summer compared with other seasons, respectively, -8.1, -6.3 and -8g.

The best QIC were reached when the interaction schooling/seasons was removed from the model. When the interaction between seasons and gender was considered (Table 2) we found that gender changed the effect of the seasons in energy, carbohydrate and total fat intake and showed a borderline significance for calcium $(p=0.061)$. When we analyzed differences within gender groups, among men we found higher total fat intake in autumn and in spring compared to summer, and a higher carbohydrate intake in summer (Figure 1). Although the p-values for multiple comparisons showed a significant interaction between season and gender for energy (Table 2), no statistical significance was observed within the gender groups (Figure 1).

The interaction between seasons and age was present for energy, protein, carbohydrate, total fat

\section{Table 1}

Sample description of repeated measures and economic and demographic characteristics. South of Brazil $(n=143)$.

\begin{tabular}{lcc}
\hline Variables & $\mathbf{n}$ & $\%$ \\
\hline $\begin{array}{l}\text { Total number of repeated measures } \\
\text { Seasons }\end{array}$ & 792 & \\
$\quad$ Summer & & \\
$\quad$ Autumn & 214 & 27.0 \\
Winter & 227 & 28.7 \\
Spring & 210 & 26.5 \\
Gender & 141 & 17.8 \\
Female & & \\
Male & 114 & 70.3 \\
Age (years old) & 48 & 29.7 \\
20-39 & & \\
40-69 & 92 & 55.6 \\
Education (years of study) & 70 & 44.4 \\
Less than 8 & & \\
9-11 & 34 & 12.8 \\
More than 12 & 44 & 28.9 \\
& 84 & 58.3 \\
\hline
\end{tabular}


Table 2

Mean differences in energy and nutrient intake between seasons and statistical significance (p-value). South of Brazil ( $n=143)$.

\begin{tabular}{|c|c|c|c|c|c|c|c|c|c|}
\hline \multirow[t]{3}{*}{ Nutrient intake } & \multicolumn{7}{|c|}{ Summer } & \multirow{2}{*}{\multicolumn{2}{|c|}{$\begin{array}{l}\text { Winter } \\
\text { Spring }\end{array}$}} \\
\hline & \multicolumn{2}{|c|}{ Autumn } & \multicolumn{2}{|c|}{ Winter } & \multicolumn{3}{|r|}{ Spring } & & \\
\hline & $\begin{array}{c}\text { Mean } \\
\text { difference }\end{array}$ & p-value & $\begin{array}{c}\text { Mean } \\
\text { difference }\end{array}$ & $\mathrm{p}$-value & & $\begin{array}{c}\text { Mean } \\
\text { difference }\end{array}$ & $\mathrm{p}$-value & $\begin{array}{c}\text { Mean } \\
\text { difference }\end{array}$ & $p$-value \\
\hline Energy (kcal) & 98.68 & 1.000 & 34.21 & 1.000 & & 81.90 & 1.000 & 47.69 & 1.000 \\
\hline Protein (g) & 0.52 & 1.000 & -3.06 & 1.000 & & -0.81 & 1.000 & 2.25 & 1.000 \\
\hline Carbohydrate (g) & 15.79 & 0.019 & 18.08 & 0.007 & & 18.32 & 0.007 & 0.24 & 1.000 \\
\hline Total fat (g) & -8.09 & 0.001 & -6.38 & 0.004 & & -8.00 & 0.001 & -1.62 & 1.000 \\
\hline Cholesterol (mg) & -12.17 & 1.000 & -38.02 & 0.917 & & -5.33 & 1.000 & 32.68 & 1.000 \\
\hline Total fiber (g) & -0.56 & 1.000 & -1.36 & 0.977 & & 0.23 & 1.000 & 1.59 & 0.977 \\
\hline Calcium (mg) & 50.26 & 0.826 & 80.35 & 0.087 & & 57.74 & 0.826 & -22.61 & 1.000 \\
\hline Iron (mg) & 0.77 & 1.000 & 0.49 & 1.000 & & 0.21 & 1.000 & -0.28 & 1.000 \\
\hline Vitamin C (mg) & 6.45 & 1.000 & 0.13 & 1.000 & & 8.20 & 1.000 & 8.07 & 1.000 \\
\hline Retinol * (mcg retinol) & -20.63 & 1.000 & -12.62 & 1.000 & & -32.37 & 0.829 & -19.75 & 1.000 \\
\hline \multirow[t]{3}{*}{ Nutrient intake } & \multicolumn{5}{|c|}{ Autumn } & \multicolumn{4}{|c|}{ p-value to multiple comparisons ** } \\
\hline & \multicolumn{2}{|c|}{ Winter } & \multicolumn{3}{|c|}{ Spring } & & & & \\
\hline & $\begin{array}{c}\text { Mean } \\
\text { difference }\end{array}$ & $p$-value & $\begin{array}{c}\text { Mean } \\
\text { difference }\end{array}$ & & $\mathrm{p}$-value & & Season $* \star \star$ & Gender \# & Age \#\# \\
\hline Energy (kcal) & -64.47 & 1.000 & -16.79 & & 1.000 & & 0.710 & 0.002 & 0.016 \\
\hline Protein (g) & -3.58 & 1.000 & -1.33 & & 1.000 & & 0.650 & 0.105 & 0.041 \\
\hline Carbohydrate (g) & 2.29 & 1.000 & 2.53 & & 1.000 & & 0.003 & 0.005 & 0.003 \\
\hline Total fat (g) & 1.70 & 1.000 & 0.09 & & 1.000 & & $<0.001$ & 0.001 & 0.001 \\
\hline Cholesterol (mg) & -25.84 & 1.000 & 6.84 & & 1.000 & & 0.551 & 0.703 & 0.571 \\
\hline Total fiber (g) & -0.80 & 1.000 & 0.79 & & 1.000 & & 0.441 & 0.544 & 0.430 \\
\hline Calcium (mg) & 30.08 & 0.928 & 7.48 & & 1.000 & & 0.110 & 0.061 & 0.026 \\
\hline Iron (mg) & -0.28 & 1.000 & -0.56 & & 1.000 & & 0.487 & 0.338 & 0.847 \\
\hline Vitamin C (mg) & -6.32 & 1.000 & 1.76 & & 1.000 & & 0.937 & 0.107 & 0.193 \\
\hline Retinol * (mcg retinol) & 8.01 & 1.000 & -11.73 & & 1.000 & & 0.503 & 0.502 & 0.752 \\
\hline
\end{tabular}

* Retinol without outliers;

** All analyses were adjusted for gender, age, schooling and interaction (gender/seasons, age/seasons);

*** Comparison among seasons;

\# Analysis for interaction between gender and seasons;

\#\# Analysis for interaction between age and seasons.

and calcium intake (Table 2). Differences within age groups were seen only for carbohydrate and total fat, and only among younger individuals. Subjects aged from 20 to 39 years had higher carbohydrate intake in summer than autumn $(\mathrm{p}=0.005)$ and higher total fat intake in autumn and winter than in summer (Figure 2).

\section{Discussion}

This is an exploratory study aimed at evaluating the seasonal effect on energy and nutrient intake of adults living in the Metropolitan area of Porto
Alegre. Porto Alegre is located in the temperate zone, and because of the marked seasonal variations in climate, differences in dietary intake were expected. In general, the results showed differences in intake according to seasons for carbohydrate and total fat, after controlling for gender, age, education, and interactions between season and gender, and season and age. In summer the carbohydrate intake was higher than other seasons while the total fat intake was lower.

Seasonal variation of dietary intake has been studied in convenience samples throughout the world. Hebert et al. 21 found large inter-person 
Figure 1

Interaction between seasons and gender *. South of Brazil $(n=143)$.

1a) Mean energy intake (kcal) **

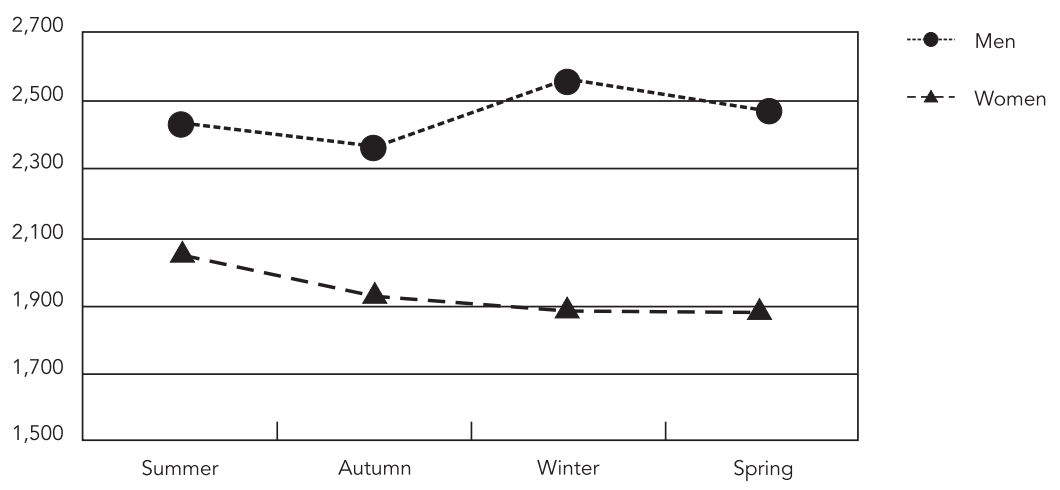

1b) Mean carbohydrate intake (g)

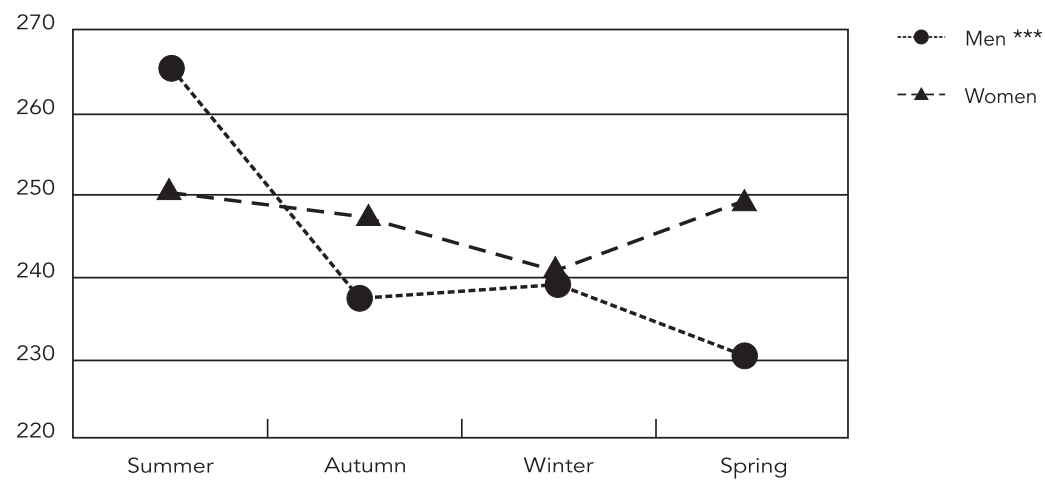

1c) Mean total fat intake (g)

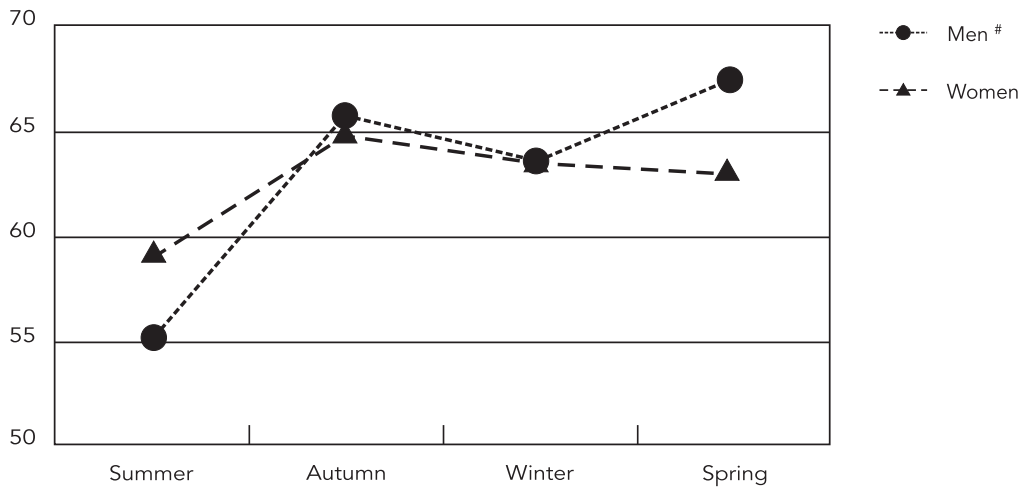

* Analysis controlled for gender, age, education and interactions;

** Note: there was no statistical difference within groups;

*** $p$-value for differences between summer and autumn intake $(p=0.040), p$-value for differences between summer and spring intake $(p=0.002)$;

\# $p$-value for difference between summer and autumn intake $(p=0.019)$, $p$-value for difference between summer and spring intake $(p=0.011)$. 
Figure 2

Interaction between seasons and age groups *. South of Brazil $(n=143)$.

2a) Mean energy intake (kcal) **

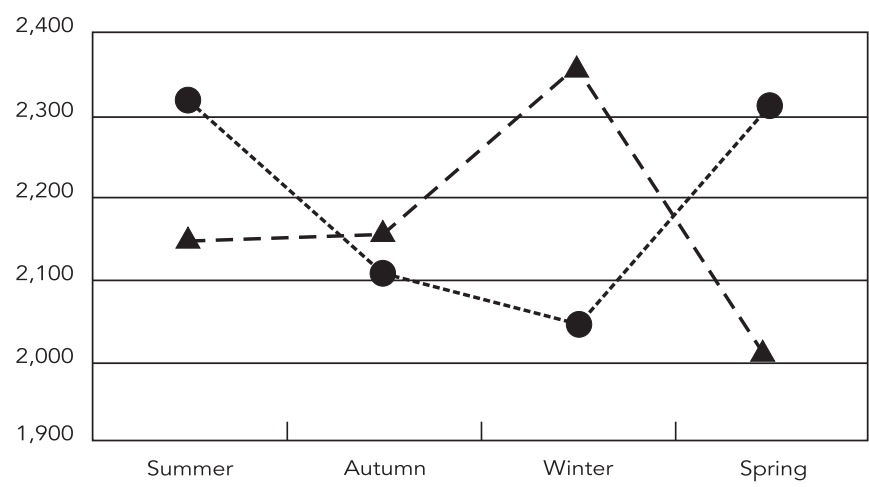

- 20-39 years

-.... 40 or more years

2b) Mean protein intake $(\mathrm{g})$ **

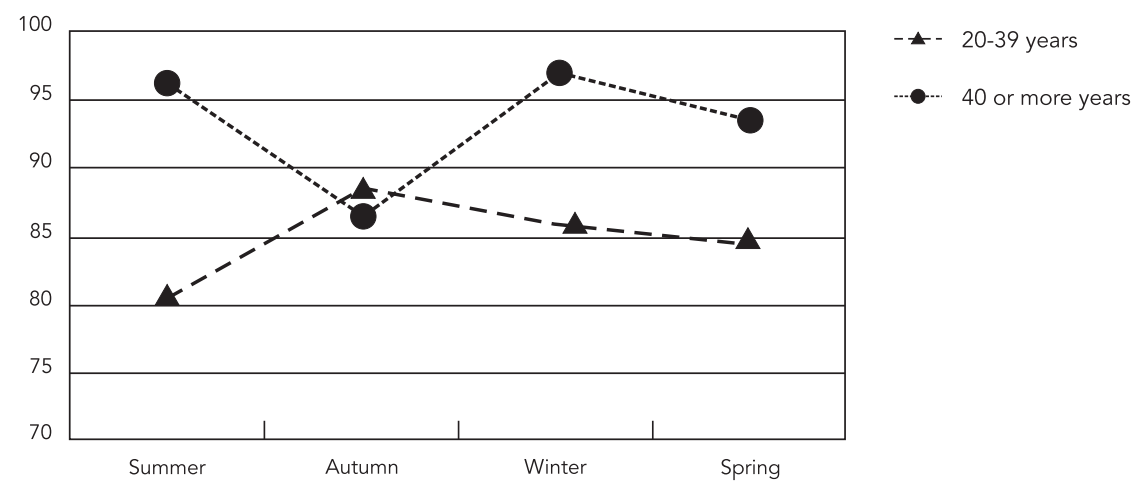

2c) Mean carbohydrate intake (g)

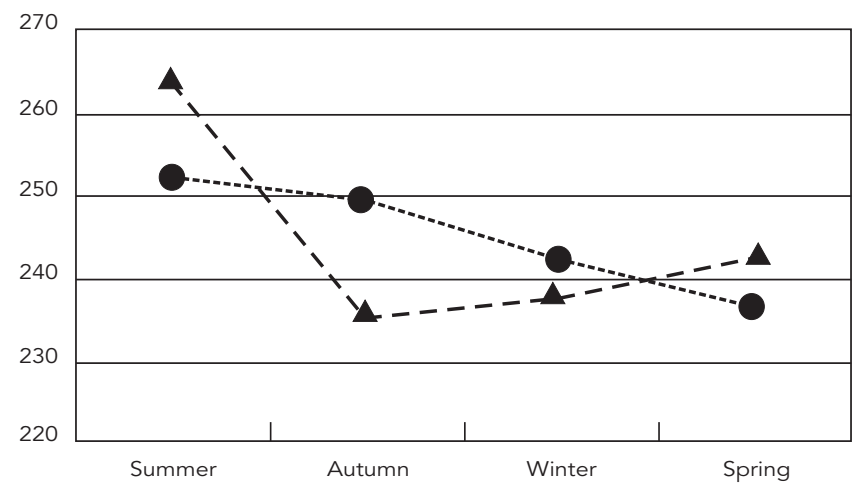

- - 20-39 years ***

-.... 40 or more years 


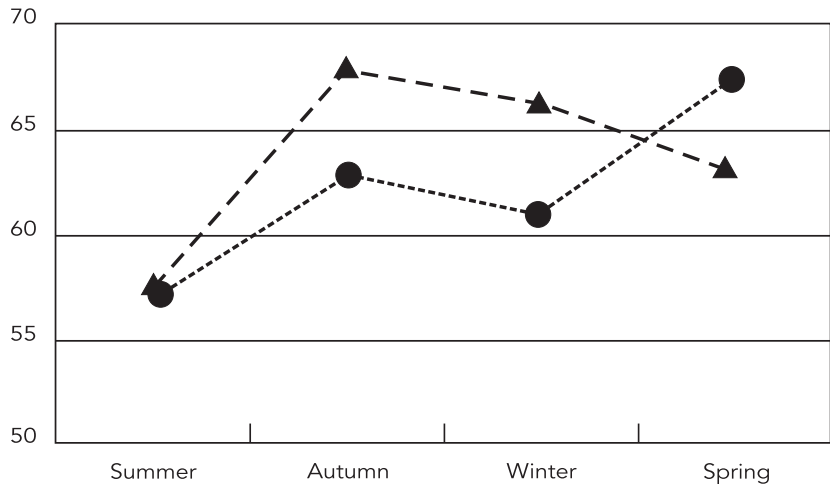

2e) Mean calcium intake (mg)

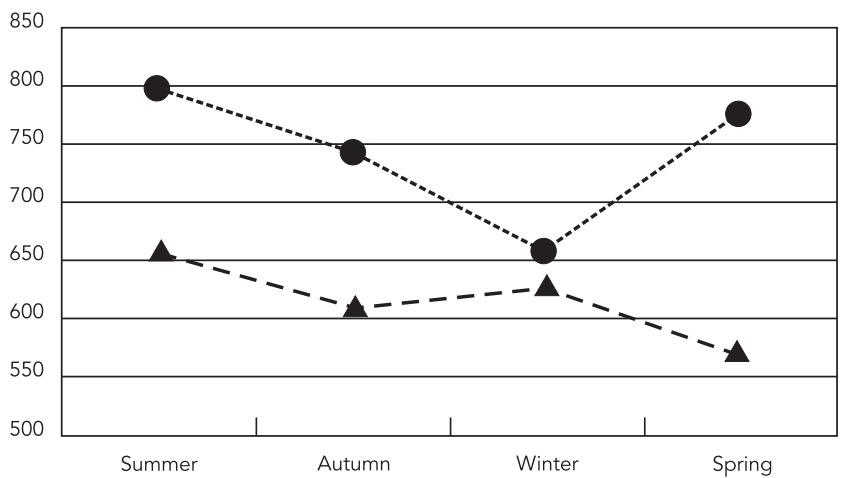

- $-20-39$ years

-.-... 40 or more years

* Analysis controlled for gender, age, education, and interactions;

** There was no statistical difference within groups;

*** $p$-value for difference between summer and autumn intake $(p=0.005), p$-value for difference between summer and winter intake $(p=0.058)$;

\# $p$-value for difference between summer and autumn intake $(p<0.001)$, $p$-value for difference between summer and winter intake $(p=0.032)$.

variability but very little of the variance in dietary intake could be ascribed to season in a study in two regions in rural India using $24 \mathrm{hR}$. In the dietary calibration studies for the Shanghai Health Study, the total variation derived from the seasonal effect and the variation due to methodological issues such as the day of the week and the sequence of interviews was less than $5 \%$, and did not represent an important source of variation in food intake. This study was based on $24 \mathrm{hR}$ administered biweekly during 1 year in a sample of healthy urban Chinese men $(n=96) 22$ and women $(n=200) 23$. In another similar study conducted with a Japanese population, the con- tribution of the season on total variation ranged from 0.1 to $2.7 \% 24$.

In a similar tendency to our study, Fowke et al. 25 compared the average nutrient intake in each season with the annual average intake and observed an increase in fat and reduction in carbohydrate intake in winter. However, different from our findings, they also found differences for protein between seasons.

In our study, we found an interaction between season and gender to energy intake but there were no differences within gender groups. However, the increase of $200 \mathrm{kcal}$ in winter in relation to autumn in the men group deserves at- 
tention because it can be considered clinically relevant. In a study by Fowke et al. 25 with 74,958 individuals that aimed to investigate the effect of season on FFQ administration, statistically significant differences were found only for women. For them, there was an increase in energy intake from summer to winter. In contrast, Westerterp et al. 26 found increased energy intake in winter in comparison to summer in a sample of $27 \mathrm{di}$ etitian women. In another study carried out in northwest Spain, comparing summer and winter, there was a statistically significant increase in energy intake in winter only in men ${ }^{27}$. Similar results were observed in 94 male Israeli industrial employees, but they were not statistically significant 28 .

Interaction between season and gender also was observed for carbohydrate intake, but statistically significant differences were found only for men. The intake was lower in autumn and spring in relation to summer. In contrast, in the study conduced for Cappita \& Alonso-Calleja 27 in Spain, men consumed less carbohydrate in summer.

Similar to carbohydrate, gender changed the effect of season in total fat intake and differences were found only for men too. The total fat intake was lower in summer when compared to autumn and spring. Shahar et al. 29 also observed lower total fat intake in summer for men, when comparing with winter. According to the authors, the increase in fat intake in winter was attributed to higher consumption of meat, dairy product and eggs.

The energy, protein, carbohydrate, total fat and calcium intakes in the seasons also varied according to age groups. Studies testing the seasonal effect on nutrient intakes according to age were not found, which did not permit comparisons with our results.

Although differences within each age group were not significant, it is noteworthy that the young subjects did not reach the minimum recommended intake of calcium in any season 30 . Moreover, the reduction of approximately 100mg of calcium intake from summer to winter among the 40 and more year-old group may represent a risk.

The comparison between this and other studies developed around the world is relevant, but it is important to consider that there is a large difference in several aspects influencing all findings. One of these aspects relates to statistical analyses conducted in each study. Different to all other studies identified, in our study the analysis was based on GEE 31, an extension of the General Linear Model, especially used for analyses of repeated measures with non-normal distri- bution data. The GEE is a statistical method still underutilized in nutritional epidemiology, but it is increasingly being used to perform analyses of correlated data in longitudinal studies. On the other hand, it is difficult to conduct comparisons between nutrient intakes observed in the South of Brazil and in other parts of the world, because cultural habits and availability of foods are very different. Hence, other studies in this region are necessary to allow more comparisons, since differences were found.

One of the strengths of the current study was the methodological care required to reduce potential errors in dietary intake reported by the subjects. There was a photo album to assist in determining the size of servings of each ingested food. All researchers were well trained in the research instruments and all subjects were free of medical conditions that could interfere with normal eating habits. One weekend day was included, in accordance with recommendations for food surveys, in order to obtain information from an atypical day and help represent the dietary habits of the individuals 16 .

However, some details should be considered in interpreting our findings. This paper addresses nutrients instead of foods, so the seasonal variations could be attributed to the differences in the foods eaten, which was not assessed in the present analysis.

One should also consider the number of days of diet data to be collected. It is well established that food intake on a single day, most probably, does not capture the pattern of usual intake 16 of an individual. In our study this number ranged from 1 to 3 . In each season, on average, 30 individuals completed one, 25 two, and 39 three $24 \mathrm{hR}$. Although the number of recalls in each season was greater than one for most participants, we know that for some nutrients there is a wide variation in day-to-day intake and more days of dietary surveys would be needed. According to Tokudome et al. 24 , the number of $24 \mathrm{hR}$ or food record replications necessary for estimating nutrient consumption per person within $20 \%$ of the true mean for female Japanese dietitians ranged from 3 to 9 for energy and for macronutrients, and from 4 to 160 for specific micro-nutrients.

The results of this study should be viewed with caution, since the sample used is non-probabilistic and is characterized by having a high level of education. About $60 \%$ of this sample had completed undergraduateor graduate courses. In accordance to the national survey conducted in 2000 (Brazilian Institute of Geography and Statistics. 2000 Demographic Census. http://www. ibge.gov.br), only $1.88 \%$ of the population were 
college laureated and less than $1 \%$ had graduate degrees.

Although we have not found differences between seasons for most nutrients, the seasonal variation observed for the intake of some nutrients should be viewed with concern, since the elements for maintaining a good level of health include the regular consumption of food in adequate quantity and quality 32 . This is especially important for energy and macro-nutrient intake because of increasing levels of obesity 32 , and calcium intake among older people, due to the greater risk of developing osteoporosis 33 , and for young people who are at the peak stage of bone mass formation ${ }^{34}$. Additionally, it is note- worthy that a recent study identified an inverse association between calcium intake and type 2 diabetes 35 . Thus, cyclic variation of this nutrient intake may represent an important public health problem.

In conclusion, these findings highlight the importance of considering seasonal variations not only for evaluating dietary intake but also nutrition and public health policy recommendations, particularly in energy and macro-nutrient intakes in adult populations living in the temperate zone. The effect of season on food intake depends on gender and age and the differences in climate between seasons.

\section{Resumo}

Avaliar o efeito da sazonalidade sobre a ingestão de nutrientes em adultos residentes em Porto Alegre e Região Metropolitana, no Sul do Brasil. A ingestão alimentar foi obtida por meio de recordatórios alimentares de 24 horas em uma amostra de 162 adultos, com idade entre 20 e 69 anos. A ingestão média de nutrientes para cada estação do ano foi ajustada pela energia total usando o método dos resíduos. O efeito das estações do ano sobre a ingestão de energia, macro e micro-nutrientes foi analisado com base no modelo de Equações de Estimação Generalizado (GEE). Houve diferenças estatisticamente significativas entre as estações do ano para a ingestão de carboidratos e gordura total após ajuste para sexo, idade, educação e interações. No verão a ingestão de carboidrato foi maior do que nas outras estações e a ingestão de gordura foi menor. Os resultados sugerem que o efeito da variação sazonal sobre a ingestão de nutrientes deve ser considerado em estudos de avaliação da ingestão dietética e recomendações, especialmente em adultos residentes em zonas temperadas como a região Sul do Brasil.

Ingestão de Alimentos; Recomendações Nutricionais; Estações do Ano

\section{Contributors}

M. T. A. Olinto participated in the coordination of the study, its planning and execution and the write up of the article. S. L. Rossato contributed with data collection and analysis and the article write up. R. L. Henn was involved in the planning, analysis and write up. L. A. Anjos participated in the planning, research supervision and write up. A.W. Bressan contributed in the supervision of the field work and review of the manuscript. V. Wahrlich supervised the field work and training and reviewed the article. The final version was approved by all authors.

\section{Acknowledgments}

Thanks to the Graduate Studies Coordinating Board (CAPES; PROCAD 01/2005 $\mathrm{n}^{\circ} .0257052$ e PROSUP $\mathrm{n}^{\mathrm{o}}$. 097/2007) and the National Research Council (CNPq; no. 308833/2006, no. 308489/2009-8 and no. 311801/2006-4). 


\section{References}

1. Brown KH, Black RE, Becker S. Effects of season and illness on the dietary intake of weanlings during longitudinal studies in rural Bangladesh. Am J Clin Nutr 1985; 41:343-55.

2. Brown KH, Black RE, Becker S. Seasonal changes in nutritional status and the prevalence of malnutrition in a longitudinal study of young children in rural Bangladesh. Am J Clin Nutr 1982; 36:303-13.

3. Lam RW, Golder EM, Grewal A. Seasonality of symptoms in anorexia and bulimia Nervosa. Int J Eat Disord 1996; 19:35-44.

4. Partonen T, Lonnqvist J. Seasonal affective disorder. Lancet 1998; 352:1369-74.

5. Plasqui G, Kester AD, Westerterp KR. Seasonal variation in sleeping metabolic rate, thyroid activity, and leptin. Am J Physiol Endocrinol Metabol 2003; 285:E338-43.

6. Tetens I, Hels O, Khan NI, Thilsted SH, Hassan N. Rice-based diets in rural Bangladesh: how do different age and sex groups adapt to seasonal changes in energy intake? Am J Clin Nutr 2003; 78:406-13.

7. Ala-Houhala M, Koskinen T, Parviainen MT, Visakorpi JK. 25-hydroxyvitamin D and vitamin D in human milk: effects of supplementation and season. Am J Clin Nutr 1998; 48:1057-60.

8. Bleiler RE, Yearick ES, Schnur SS, Singson IL, Ohlson MA. Seasonal variation of cholesterol in serum of men and women. Am J Clin Nutr 1963; 12:12-6.

9. Minghelli G, Schutz Y, Whitehead R, Jéquier E. Seasonal changes in 24-h and basal energy expenditures in rural Gambian men as measured in a respiration chamber. Am J Clin Nutr 1991; 53:14-20.

10. Fahey MT, Sasaki S, Kobayashi M, Akabane M, Tsugane S. Seasonal misclassification error and magnitude of true between-person variation in dietary nutrient intake: a random coefficient analysis and implications for the Japan Public Health Center (JPHC) Cohort Study. Public Health Nutr 2003; 6:385-91.

11. Locke E, Coronado GD, Thompson B, Kuniyuki A. Seasonal variation in fruit and vegetable consumption in a rural agricultural community. J Am Diet Assoc 2009; 109:45-51.

12. Morgado IF, Aquino CNP, Terra DCT. Aspectos econômicos da cultura do abacaxi: sazonalidade de preços no Estado do Rio de Janeiro. Rev Bras Frutic 2004; 26:44-7.

13. Instituto Brasileiro de Geografia e Estatística. Pesquisa de Orçamentos Familiares 2002-2003: primeiros resultados. Brasil e grandes regiões. Rio de Janeiro: Instituto Brasileiro de Geografia e Estatística; 2004.

14. Levy-Costa RB, Sichieri R, Pontes NS, Monteiro CA. Disponibilidade domiciliar de alimentos no Brasil: distribuição e evolução (1974-2003). Rev Saúde Pública 2005; 39:530-40.

15. Zanolla AF, Olinto MTA, Henn RL, Wahrlich V, Anjos LA. Avaliação de reprodutibilidade e validade de um questionário de freqüência alimentar em adultos residentes em Porto Alegre, Rio Grande do Sul, Brasil. Cad Saúde Pública 2009; 25:840-8.

16. Willett WC. Nutritional epidemiology. $2^{\text {nd }}$ Ed. New York: Oxford University Press; 1998.
17. Lenz A, Olinto MTA, Dias-da-Costa JS, Alves AL, Balbinotti M, Pattussi MP, et al. Socioeconomic, demographic and lifestyle factors associated with dietary patterns of women living in Southern Brazil. Cad Saúde Pública 2009; 25:1297-306.

18. Bossan FM, Anjos LA, Vasconcellos MTL, WahrlichV. Nutritional status of the adult population in $\mathrm{Ni}$ terói, Rio de Janeiro, Brazil: the Nutrition, Physical Activity, and Health Survey. Cad Saúde Pública 2007; 23:1867-76.

19. Pinheiro ABV, Lacerda EMA, Benzecry EH, Gomes MCS, Costa VM. Tabela para avaliação de consumo alimentar em medidas caseiras. 5a Ed. São Paulo: Editora Atheneu; 2005.

20. Altman DG. Practical statistics for medical researches. London: Chapman \& Hall; 1997.

21. Hebert JR, Gupta PC, Mehta H, Ebbeling CB, Bhonsle RR, Varghese F. Sources of variability in dietary intake in two distinct regions of rural India: implications for nutrition study design and interpretation. Eur J Clin Nutr 2000; 54:479-86.

22. Cai H, Yang G, Xiang YB, Hebert JR, Liu DK, ZhengW, et al. Sources of variation in intake among men in Sanghai China. Public Health Nutr 2005; 8:1293-9.

23. Cai H, Shu XO, Hebert JR, Jin F, Yang G, Liu DK, et al. Variation in nutrient intakes among women in Shanghai, China. Eur J Clin Nutr 2004; 58:1604-11.

24. Tokudome Y, Imaeda N, Nagaya T, Ikeda M, Fujiwara N, Sato J, et al. Daily, weekly, seasonal, within- and between-individual variation in nutrient intake according to four season consecutive 7 day weighed diet records in Japanese female dietitians. J Epidemiol 2002; 12:85-92.

25. Fowke JH, Schlundt D, GongY, Jin F, Shu XO, Wen W, et al. Impact of season of food frequency questionnaire administration on dietary reporting. Ann Epidemiol 2004; 14:778-85.

26. Westerterp KR, Plasqui G, Goris AHC. Water loss as a function of energy intake, physical activity and season. Br J Nutr 2005; 93:199-203.

27. Capita R, Alonso-Calleja C. Differences in reported winter and summer dietary intakes in young adults in Spain. Int J Food Sci Nutr 2005; 56:431-43.

28. Shahar DR, Froom P, Harari G, Yerushalmi N, Lubin F, Kristal-Boneh E. Changes in dietary intake account for seasonal changes in cardiovascular disease risk factors. Eur J Clin Nutr 1999; 53:395-400.

29. Shahar DR, Yerushalmi N, Lubin F, Froom P, Shahar A, Kristal-Boneh E. Seasonal variations in dietary intake affect the consistency of dietary assessment. Eur J Epidemiol 2001; 17:129-33.

30. Suitor CW, Meyers LD. Dietary reference intakes research synthesis: workshop summary. Washington DC: National Academy of Sciences; 2007.

31. Liang KY, Zeger SL. Longitudinal data analysis using generalized linear models. Biometrika 1986; 73:13-22.

32. Joint WHO/FAO Expert Consultation on Diet, Nutrition and the Prevention of Chronic Diseases. Diet, nutrition and the prevention of chronic diseases: report of a joint $\mathrm{WHO} / \mathrm{FAO}$ expert consultation. Geneva: World Health Organization; 2002. (WHO Technical Report Series, 916). 
33. Riggs BL, Melton 3rd LJ. Involutional osteoporosis. N Eng J Med 1986; 314:1676-86.

34. Hallberg L, Rossander-Hultén L, Brune M, Gleerup A. Calcium and iron absorption: mechanism of action and nutritional importance. Eur J Clin Nutr 1992; 46:317-27.
35. Villegas R, Gao YT, Dai Q, Yang G, Cai H, Li H, et al. Dietary calcium and magnesium intakes and the risk of type 2 diabetes: The Shanghai Women's Health Study. Am J Clin Nutr 2009; 89:1059-67.

Submitted on 07/Aug/2009

Final version resubmitted on 04/Mar/2010

Approved on 04/May/2010 